Review Article

\title{
An Examination of Some Key Issues on Legal and Policy Environment in the Mining Sector After the Economic Reforms in Tanzania
}

\author{
Muhanga Mikidadi \\ Department of Development Studies, College of Social Sciences andHumanities, Sokoine University of Agriculture, Morogoro, Tanzania \\ Email address: \\ mikidadi@sua.ac.tz, mikid.muhanga@gmail.com
}

\section{To cite this article:}

Muhanga Mikidadi. An Examination of Some Key Issues on Legal and Policy Environment in the Mining Sector After the Economic Reforms in Tanzania:. International and Public Affairs. Vol. 3, No. 2, 2019, pp. 33-42. doi: 10.11648/j.ipa.20190302.11

Received: June 24, 2019; Accepted: July 18, 2019; Published: August 13, 2019

\begin{abstract}
Due to the economic hardships Tanzania has been undergoing since the early 1980s, a wide-ranging reforms in numerous sectors of the economy have been instigated. These reforms aimed at overcoming such hardships in order to improve the prospects for development. This article examines some key issues on legal and policy environments in the mining sector after the economic reforms in Tanzania, it specifically:-(i) analyses the mining sector before the reforms, (ii) examines the legal and policy responses after the economic reforms; (iii) analyses how these policies and legislations have impacted the socioeconomic and political aspects related to mining in Tanzania; and, (iv) identify the lessons learnt. A documentary review (documentary research method) was used in collecting relevant information. It was revealed that prior to the reforms the extent of minerals extraction in Tanzania was low, dominated by mineral sector development operations which were largely state owned and run by government enterprises. The legal and policy responses examined include the Mineral Policy of 1997, Mineral Act of 1998, Mining Act of 2010, New Investment Policy and the Tanzania Investment Act No. 26 of 1997 , Mining (Environmental Management and Protection) Regulations of 1999, Natural Wealth and Resources (Permanent Sovereignty) Act, 2017; Natural Wealth and Resources Contracts (Review and Re-Negotiation of Unconscionable Terms) Act, 2017, the Written Laws (Miscellaneous Amendments) Act 2017; Extractive Industry Transparency and Accountability Act, 2015 and the Finance Act of 2017. These legal and policy responses in the mining sector were found to have both positive and negative impacts. It has been observed that reforms in the sector have not fully captured the expectations of Tanzanians. The role of mining sector in economic development and socio-economic wellbeing is very obvious; hence transforming this resource wealth into wellbeing remains essential matter for Tanzania's economy. It is recommended that conducive legal and policy framework enhanced to transform mineral resources into wellbeing.
\end{abstract}

Keywords: Legal and Policy Environment, Mining Sector, Economic Reforms, Tanzania

\section{Background Information}

The government of Tanzania (GoT) embarked on economic reforms in the 1980 s following financial crisis that faced the country $[10,22-26]$. The major reforms undertaken by the GoT included Tanzania's own structural adjustment programme; National Economic Survival Programme (NESP) in 1981 and the Structural Adjustment Programme (SAP) in 1983, followed by a donor-sponsored Economic Recovery Programme (ERP) in 1986. Tanzania signed an agreement with the World Bank and the IMF in
1986 to adopt SAPs. These included the Economic Recovery Programme One (ERP I) in 1986, ERP II, Economic and Social Action Plan (ESAP) and the Priority Social Action Plan (PSAP) in 1989 [16]. The aims of these programmes were to achieve sustainable growth in real income and output, better pricing of crop production, improved product and input marketing, an increase in government outlays for agriculture and an increase in industrial capacity utilization by liberalizing raw material imports. The reforms also aimed at decreasing the balance of payments deficit through devaluation, export incentive 
schemes, and foreign exchange liberalization, and better control of the budget deficit and money supply. These were thought to be key ingredients necessary to economic recovery. In 1989, the ERP programme was modified to create ESAP. The goal of the new programme was to restore the physical infrastructure and ease social impacts $[33,21]$.

As any other sector of the economy in Tanzania, the mining sector has not escaped reforms undertaken by the government from the mid-1980s [23, 24]. This has resulted, among others, into the increase of Foreign Direct Investment (FDIs) [39, 5, 57], also contribution of the mining and manufacturing sectors of total FDI stock to more than 60 per cent [39].

The turn of the century has witnessed the mining sector becoming one of the most important economic activities in a growing number of low-income and middle income countries $[58,39,5,46]$. This is partly due to rise in price of minerals in 2000s and having a number of reform programmes working successfully in some countries [32, 17, 5]. The economic reforms in Tanzania involved changes (amendment) in legal framework and supportive policies [23, 5]. It involved reforming mining legislations (mine code, implementing regulations, investment agreements), reforming mining taxation to internationally comparable standards, strengthening institutions through re-organizing government agencies responsible for supervision of the sector, strengthening environmental protection legislation and government departments, improving the technical, environmental and social conditions of small scale miners, privatizing state owned enterprises, just to mention a few [17].

Tanzania with assistance from the World Bank embarked on these initiatives in the context of reforming the mining sector. A substantial literature [14, 23, 24, 59] has discussed the benefits gained by local communities living close to mining centers; some [1, 11, 59] have discussed mining and environmental issues; and also on community relations and social responsibility [9], with very little attention being paid to the legal and policy environment. This paper examines some key issues in connection to mining sector after economic reforms in Tanzania reflecting legal and policy environment plus its "socio-politiconomics" implications. Specifically the discussion is on the Mineral Policy of Tanzania of 1997, Mineral Act of 1998, Mining Act of 2010, New Investment Policy and the Tanzania Investment Act No. 26 of 1997, Mining (Environmental Management and Protection) Regulations of 1999, Natural Wealth and Resources (Permanent Sovereignty) Act, 2017, Natural Wealth and Resources Contracts (Review and ReNegotiation of Unconscionable Terms) Act, 2017 and the Written Laws (Miscellaneous Amendments) Act 2017; Finance Act of 2017; Extractive Industry Transparency and Accountability Act, 2015 and how these policies and legislations have impacted the socio-economic and political aspects related to mining in Tanzania plus the lessons learnt from the reforms.

\section{Method}

This article summarizes the legal and Policy Environment in the Mining Sector following Economic Reforms in Tanzania nearly Thirty Years Plus after by examining some key issues. In this paper previously published studies has been surveyed and summarized, as review article this paper doesn't report new facts or analysis.

A documentary review (documentary research method) was used in collecting relevant information for this article. It is the analysis of documents that contain information about the phenomenon under a study $[60,20]$. Documentary method is described as the techniques used to categorize, investigate, and interpret written documents whether in the private or public domain [20].

The exercise involves analytic reading and review of lots of written materials; it helps the researcher to extract the relevant portions that can be deemed as statements of facts to validate individual research objectives. This method is superior and sometimes even more cost effective than social surveys, in-depth interviews or participant observation [49].

\section{Results}

\subsection{Mining Sector in Tanzania Before the Reforms: An Overview}

Evidently, Tanzania is amongst Africa's most mineral-rich countries; it is indeed the fourth country with richness of mineral resources in Africa [39, 5]. The minerals in Tanzania remained untapped and underutilized prior to the reforms. Prior to the reforms there was no existence of foreign investments as foreign investments were perceived as capitalistic and exploitative, following the adoption of Tanzania's ideology of "Ujamaa na Kujitegemea" in 1967 [24].

Around 1970 s to 1980 s, the mineral sector development operations were largely state owned under the National Development Corporation (NDC), and later the State Mining Corporation (STAMICO). The mining activities were not allowed without the state participation [19]. However, from the late 1980 s to 1995 artisanal and small-scale mining activities started to boom, reported to employ around 500,000 people in mining and trade activities characterized by a gold rush whereby many people from both local communities and urban centres started to get heavily involved with gold mining [19]. Despite being illegal, artisanal mining became a common feature of the mining sector $[12,48,31]$.

Prior to privatization in the mid-1990s, exploitation of minerals was limited [38], but the 1998 Mining Act aimed to incentivize private investment into mining. The official gold production figures displayed an increase between 1985 and 1992 to 4 tones in 1992 due to gold buying programme initiated to buy all the gold from the small scale and artisanal miners [19].

\subsection{People's Expectations from the Reform}

For over 20 years the World Bank was influential in 
providing technical assistance to countries in Latin America, Africa, and Eastern Europe, East Asia and the Pacific, and Central Asia to help reform mining sectors [17, 51-56]. The evolution from an emphasis on increasing investment to promoting sustainable development is illustrated by the extractive industries value chain, whereby countries pass through five stages or links in the transformation of their mineral abundance: (i) the mineral legislation is sufficiently attractive to induce investment in the sector; (ii) the regulatory framework is clear and comprehensive and there is adequate capacity for monitoring and enforcement; (iii) collection of taxes and royalties is done in a transparent and efficient manner; (iv) governments are able and willing to manage and allocate fiscal revenues efficiently; and (v) the mineral sector is contributing to the sustainable socioeconomic development of the country, whether as an engine of growth or a generator of large amounts of fiscal revenues. Success in this final stage signifies that the mining sector is having an important impact directly and indirectly on poverty reduction and broad-based, sustainable socio-economic development.

\subsection{Legal and Policy Responses in the Mining Sector}

The government of Tanzania, by the mid-1980s, realized that the past development policies and strategies were not adequately responding to changing market and technological conditions in the regional and world economy and were also not adapting to changes in the domestic socio-economic conditions [23]. To that effect, a number of legal and policy responses to the economic reforms were put in place in the mining sector.

\subsubsection{The Mineral Act of 1998}

The Mining Act 1998, among other features, provided right to trade in mineral rights, simplification and consolidation of past statutes on mining and mineral trading and improving security of tenure through removal of most past ministerial discretionary powers. The act also introduced a mining advisory committee responsible of advising the Minister on decisions to make; enhancing clarity and transparency; putting in place fair, streamlined and nondiscriminatory licensing procedure, and, Environmental management [43]. The Tanzania's mining Act also aimed to deter information hoarding on new discoveries, freezing of exploration acreage for speculative purposes, transfer pricing and tax evasion. It also provides a number of fiscal incentives to exploration and mining activities including the following among others: exemption of import duty and Value Added tax (VAT) on equipment and essential materials up to the anniversary of start of production, thereafter 5 per cent seal applies; depreciation allowances of 100 per cent; repatriation of capital and profit directly related to mining, and nonmandatory government participation.

\subsubsection{The Mineral Policy of Tanzania (1997)}

The Mineral Policy of Tanzania (1997) stresses on private sector led mineral development while the major roles of the government are regulating, promoting and facilitating. The public roles consist of, inter alia, policy formulation to accommodate the overall and sectoral government policy framework. Achievement of the above is through advising on legislation, regulation and fiscal matters related to the sector, revenue collection through royalties and annual rents. Others are on prospecting rights and licenses, monitoring of mining activities, collection and maintenance of geo-technical data for promotional purposes, provision of extension services to small scale miners, administration and inspection of mining activities, and carrying out research on minerals [42].

The mineral policy objectives are: to stimulate exploration and mining activities, to regulate and improve artisanal mining, and to ensure that wealth generated from mining supports sustainable economic and social development. All the above aiming at minimising or eliminating adverse social and environmental impact of mining activities, to promote and facilitate mineral and mineral based products' marketing arrangement, to alleviate poverty especially for artisan and small scale miners, and to promote and develop Tanzania as the gemstone centre of Africa [42].

\subsubsection{The Mining Act of 2010}

The Mining Act of 2010 increased royalties, required companies to list domestically, allowed the Government to take a share in future mining projects, and restricted foreign participation in small-scale mining. The changes only brought the country's royalty rates in line with other African mining nations. The Act is more restrictive than its predecessor and is consistent with other recent legislation which seeks to concentrate a greater interest in the hands of Tanzanian nationals with increased regulation in key sectors whilst continuing to encourage inward investment.

Key provisions of the Mining Act of 2010

The Act introduces significant changes to mining policy, in particular the following:

a) Mineral rights and licenses for dealing in minerals will be reserved exclusively to Tanzanian citizens and corporate bodies under the exclusive control of Tanzanian citizens. The main point to note, however, is that the amendments significantly mitigated the Tanzanian control issue in respect of general mining licenses, and the restrictions will apply only to "primary mining licenses", which are licenses with respect to small-scale mining operations involving capital expenditure of less than $\$ 100,000$ (Section 8 and Section 73).

b) Licenses to mine for gemstones should only granted to Tanzanians, regardless of the size of the operation, except where the Minister determines that the development is most likely to require specialized skills, technology or a high level of investment. In such a case, the license can be granted to an applicant so long as the non- Tanzanian participation element is no more than $50 \%$ (Section 8 (4)).

c) The Act gives the Minister power to prescribe a standard model form Mining Development Agreement 
for all projects exceeding US $\$ 100 \mathrm{~m}$ (Section 8 (4)).

d) The Act gives the Minister power to make regulations authorizing the GoT to participate in the conduct and financing of mining operations and give the GoT a free carried interest, the level of which is not set by statute but rather by negotiation between the GoT and the relevant mineral rights holder (Section 10).

e) It amends the method by which GoT royalties are calculated to allow future levies on the gross value of minerals, rather than the present method of calculation, which refers to the net value (Section 87).

f) It increases the rates of royalties levied by the GoT on the gross value of minerals as follows:

i. Uranium - 5\%;

ii. Gemstone and diamond - 5\%;

iii. Metallic minerals (copper, gold, silver, and platinum group) - $4 \%$;

iv. Gem $-1 \%$; and

v. In the case of other minerals, including building materials, salt, all minerals within the industrial minerals group - 3\% (Section 87).

g) The Act requires a greater degree of disclosure by the holders of mineral rights in respect of reports, records and general information (Section 100 and Second Schedule).

\subsubsection{New Investment Policy and the Tanzania Investment Act No. 26 of 1997}

In 1996 the Tanzanian government issued a New Investment Policy, which was followed by the Tanzania Investment Act No. 26 of 1997. The main aims were to increase the transparency of the legal framework, deregulate the investment process, create a one stop investment agency and provide for transferability of capital and profits. This aspect was responsible for creation of conducive environment for the investors in the mining sector in Tanzania. These changes in the investment laws are associated with an increase in FDIs flows.

\subsubsection{The Mining (Environmental Management and Protection) Regulations of 1999}

This is an important policy that was meant to take care of the environment in the context of mining. The 1998 Mining Act together with the Mining (Environmental Management and Protection) Regulations of 1999 require commissioning of independent consultants of international standing selected by the project proponent and approved by the Government to carry out Environmental Impact Assessment (EIA) on the proposed mining operations. The project proponent must produce an Environmental Management Plan acceptable to the Government. Approval of a project involves screening, scoping, EIA and EMP evaluation by government experts. In addition, relevant Regional Administration, Local Government Authorities and the public are consulted and their opinions taken into account during the approval process. The approved EMP is subject to a first review by the government after two years, and thereafter every five years [28].

\subsubsection{Other Legal and Policy Framework in the Mining Sector}

In the event of what was noted by two presidential commissions, on the incidence of Acacia Mining understating the value of mineral concentrates for exports, on $29^{\text {th }}$ June 2017, the National Assembly passed three laws; these are the Natural Wealth and Resources (Permanent Sovereignty) Act, 2017; the Natural Wealth and Resources Contracts (Review and Re-Negotiation of Unconscionable Terms) Act, 2017 and the Written Laws (Miscellaneous Amendments) Act 2017 [38]. These laws were preceded by Extractive Industry Transparency and Accountability Act, 2015.

These laws largely focus on mining, introduce substantial changes in the extractive sector in Tanzania, among others, the laws contain provisions for reviewing and renegotiating existing natural resources contracts; establishing a mining commission; advancing local benefication and procurement; limiting the use of offshore bank accounts; giving to the government a non-dilutable, free-carried interest of no less than $16 \%$ in mining projects under a mining license or a special mining license; increasing royalty rates (gemstones and diamonds from $5 \%$ to $6 \%$, and for gold and other metals from $4 \%$ to $6 \%$ ); adjudicating investment disputes in domestic courts; and giving the right for the government to acquire up to $50 \%$ of any mining asset commensurate with the total tax expenditures incurred by the government in favour of a mining company.

Another important act is the Finance Act of 2017. The Finance Act of 2017 also requires mining companies to pay $1 \%$ clearing fee of the minerals for export incurred by the government in favour of a mining company.

\section{Discussion}

\subsection{The Socio-Politiconomics of the Economic Reforms in the Mining Sector}

The socio-economic reforms which continue to be implemented to date by the Government from 1980s recorded a number of impacts in various sectors of the economy.

"Structural adjustment measures recently under taken by sub-Saharan countries are similar in all essentials, their essence is the reduction of direct state intervention on the productivity and distribution sectors of the economy, restricting the state to the creation, mainly through the manipulation of fiscal and monetary instruments, of an institutional and policy framework conducive to the mobilization of private enterprise and initiative" [50,35].

The principles such as trade liberalization, creation of conducive environment for foreign investments, privatization of parastatals and advocating of minimal role of the state in the economy were introduced through SAPs. These principles have affected the Tanzanian economy and the mining sub sector respectively both positively and negatively in terms of social, political and economic aspects (sociopoliticonomics). 


\subsection{Public Concerns and Reforms in the Mining Sector}

Mining sector reforms in a number of ways were a response to concerns and outcries that the country and the people were not benefiting from the mining sector to the expected level [35, $11,13,2]$. Despite the fact that the sector accounts for nearly half of the country's exports and places it among Africa's largest exporters, yet, ordinary Tanzanians have seen little benefit from their country's exports boom [18]. Similar trends have also been observed in other parts of Africa:-

"Although the resource boom has underpinned growth in the region's commodity producers, it has been less successful in improving people's welfare. "[59: xvii]

Evidently, people residing in Africa's resource rich countries are reported to be 3 percent less literate, with shorter life expectancy by 4.5 years, and higher rates of malnutrition particularly among women and children, compared to other countries in the region [59].

Innumerable explanations exist with respect to failure of mining sector to benefit the people to the expected level, including; enactment of tax laws that are overly favourable to multinational mining companies and partially due to the business practices of the companies themselves. The situation is further exacerbated by these companies avoiding taxes altogether by claiming losses. Contradicting arguments are existing on how many Tanzanians have benefited from the mining reforms [17]. The role of mining in economic development in Africa and Tanzania in particular is very obvious [23, 6, 59]; hence transforming this resource wealth into well-being remains important issues for Africa's economies. A number of socio-political and economic impacts can be noted in the context of reforms in Tanzania which are discussed partly in this article.

\subsection{Attracting Investors}

Adoption of significant liberalization led to increased FDIs inflow into Tanzania's resource rich mining sector [40]. Tanzania has been praised by UNCTAD for having good mining incentives, which have been making the country attractive to mining companies, which in the end made it possible to experience a boom in FDIs, particularly in gold industries [40]. UNCTAD data place Tanzania in the uppermiddle ranking of African countries in terms of FDI, with its FDI stock rising from US\$2.78 billion in 2000 to US\$5.94 billion in 2007 [41]. It is argued that, Tanzania would have appeared at the bottom of this ranking in the early 1990s. With the exception of South Africa, all of the African countries that received more FDI than Tanzania in 2007 were oil and gas exporters [34]. This signifies achievement of one of the objectives of the 1997 mineral policy, which, among other things, stresses on stimulating exploration, and mining activities stressing on private sector led mineral development [42]. With changes in Tanzania's macro-economic policy to adopt free market economic policies since 1985, many private foreign and local investors have showed interest and subsequently invested in the mineral sector. In 1992, there were 10 Prospecting Licenses and nine Mining Licenses granted to private investors. The number has increased to over 5,900 Prospecting Licenses and 220 Mining Licenses in 2008 , including six special mining licenses for gold. By 2015 , 80 companies had either a mining licence or special mining licence, with 228 companies holding prospecting licences [30]. Recently, the government awarded 17 new mining licenses and transferred licenses in the year under review. It also granted 144 prospecting licenses [38].

Poor technology, lack of skilled personnel and absence of capital have been considered to be the major obstacles facing the Tanzania government towards full exploitation of mineral resources. It is against this background that the Tanzania government decided to reform its policies towards mining hence, attracting FDIs with expectation that the country would benefit. Nevertheless, it is obvious that the principal beneficiaries of the mineral wealth have largely remained the transnational companies $[8,3]$. Despite that mining remained the leading sector in terms of investment occupying $23 \%$ between 1995-2004 [19].

\subsection{Promotion of Large Scale Mining}

Through reforms large scale mining was promoted in Tanzania as it was apparent that the mining sector in Tanzania before reforms was characterized by the artisanal and smallscale mining activities [19]. The late 1980 s to 1995 was generally characterized by a gold rush involving many people from local communities and urban centres. Annual gold production from these mines increased to about 50 tones, putting Tanzania as the third leading gold producing country in Africa.

\subsection{Mining Sector's Contribution to Government Revenue}

Despite the shortfalls that were brought in by the reforms in the mining sectors in Tanzania, the mining sector continues to be one of the biggest contributor to the country's revenue through the payment of mineral royalties, employee income taxes and corporate taxes. However, there are a number of resentments on what the government is receiving from the large scale mining scales (LSMCs) versus the value of what is produced and exported [7]. It is reported that, the mining sector's contribution to Tanzania's Gross Domestic Product (GDP) of Tanzania at the time of independence was in the region of $3 \%$ to $4 \%$ but, by the 1980 s, this had dropped to only around $1 \%[14]$.

The mining sector, although small, in 2004 contributed about $3.2 \%$ Tanzania's GDP and is an important earner of foreign exchange. Recent investments, particularly in gold mining and exploration have led to the rapid expansion of the sector, and Tanzania is now on target to become an important producer in the African context. As from 2003 and 2004, the Tanzania's mining industry continued to grow with gold mining exploration and gold production, gem stones mining and trading, as well as small and artisanal mining activities experiencing a considerable increase. In 2004 the mining sector's contribution to GDP rose to $3.2 \%$ from $3 \%$ in 2003 , and the value of mineral exports rose to $17 \%$ in 2004 to US\$ 672, 5 million from US\$ 554, and 1 million in 2003. As 
is stands, minerals make up over $52 \%$ of the country's exports, of which a large part comes from gold. Other mineral resources include diamonds, coloured gemstones, coal, salt and limestone [4]. It is reported that seven-hundred thousand individuals participate in the artisanal and small scale mining sub-sector [38]. As it has been expected, mining contribution to GDP, employment, production and export of minerals have increased. For example, export earnings from mineral export increased from an average of 1 percent of total export in 1997 to 52 percent in 2013. Similarly, the contribution of mining to the GDP rose from less than 1 percent in 1997 to 3.5 percent in 2013. Also, direct employment in the large scale mining industry increased from 1,700 to 15,000 in 2013. Currently, Tanzania is Africa's fourth-largest gold producer, with the segment generating export earnings of $\$ 1.27 \mathrm{bn}$ in 2015 , a figure set to rise as gold prices rebound from lows seen last year [30].

\subsection{Public Private Partnership in the Mining Sector in Tanzania}

The government of Tanzania has managed to establish the Public-Private Partnership in the mining sector in Tanzania as the mining industry has been opened up to the private sector. This is in line with the Mineral Policy of Tanzania (1997) which stresses on private sector led mineral development while the major roles of the government are regulating, promoting and facilitating, despite the fact that a lot of debates exist on whether the government has been able to effectively respond to its roles. It is reported that the current process of extensive economic liberalization has contributed to further deepening the imbalance in the distribution of the benefits of mining in favour of transnational foreign mining companies. As a result of these incentives, Africa has been the prime destination of multinational mining corporations. FDI flows were nonexistent in the early 1990s, but changes in the investment laws have led to an increase in FDIs [3, 35].

\subsection{Changes in Royalty Rates in Mining Act (2010)}

Another important success incidence from the reform is on the changes brought about by the Mining Act (2010) in royalty rates as indicated in Table 1 . Despite the fact that the changes have not been very significant as evidenced in Table 1 , but such changes have had some economic implications on the government's revenue.

Table 1. Changes in royalty rates in Mining Act (2010).

\begin{tabular}{lll}
\hline Mineral item & $\begin{array}{l}\text { Royalty rates Mining } \\
\text { Act 1998 }\end{array}$ & $\begin{array}{l}\text { Mining Act } \\
\mathbf{2 0 1 0}\end{array}$ \\
\hline Diamonds & $5 \%$ & $5 \%$ \\
Uranium & $3 \%$ & $5 \%$ \\
Gemstones & $3 \%$ & $5 \%$ \\
Metallic minerals (copper, gold, & $3 \%$ & $4 \%$ \\
silver, platinum) & $3 \%$ & $3 \%$ \\
Other & $3 \%$ & \\
\hline
\end{tabular}

It is claimed that, despite Tanzania's mineral resource royalty rates being r3eviewed, it is obvious they are still low by both African and global standards. Tanzania's relative governance weakness is attributed to this in comparison to some other African countries with respect to royalty rates is then compared with Ghana (sliding between 3 and 12\%), Mozambique (between 3 and $8 \%$ ), and Botswana (royalty on gold production at 5\%). [2].

\subsection{Failure to Achieve and Support Sustainable Economic and Social Development}

The reforms in the mining sector are associated with failure of achieving the central goal of the national mineral policy of ensuring that wealth generated from the mining supports sustainable economic and social development and minimizes adverse social and environmental impacts of mining activities. The government has been blamed for doing too little to ensure that the people also benefit equally from the mineral wealth $[35,11,14]$. Reforms in the mining sector in Tanzania have brought a number of public outcries, partly due to the fact that the public is well aware that the government receives as little $5 \%$ of the value of exports from the Large Scale Mining Companies (LSMCs) [40]. This developed the feeling that the reforms have failed to include the aspect of serving the purpose of development -as advocated by the founding father of the nation Mwalimu Julius Kambarage Nyerere who argued that the purpose of development is the people [29].

\subsection{Technological and Socio-Economic Issues Along the Reforms}

\subsubsection{Rise of Conflicts in the Mining Sector}

There were a number of expectations that people around the minerals rich areas had on the LSMCs operation around their places of residence including the availability of employment and training opportunities, support in health services, water supply, education facilities, improving infrastructures and expansion of the market for the local population. This has not been effected to the most people's expectations. Evidence exists [1,11] on the prevalence of a wide range of conflicts in the mining centre involving the local communities and the LSMCs. The outstanding incidences include those at North Mara, Buzwagi, and Mererani, just to mention few. It can be noted that liberalization of the mining sector also resulted into displacement and sidelining of artisanal miners, including some cases of forcefully evicting small scale miners and peasants from Bulyanhulu. In the course of eviction, it was alleged that about 54 small scale miners were buried alive when the bulldozers filled in the pits of small scale miners $[13,47,15]$. Conflicts between the mining companies and local communities /villagers is an evidence of negative aspects connected to the reforms in Tanzania. Such incidences, among others include raiding Barrick North Mara Gold Mine at North Mara, Mara Region in 2008, death and injuries of villagers as a result of confrontation with police officers and mining companies' security guards [36].

This situation later compelled the Tanzanian government to review all mining contracts following accusations that the 
contracts favor the LSMCs at the expense of the local community. In March 2017, the government banned the export of mineral concentrates, leading to a tax dispute with Acacia Mining, which operates Bulyanhulu, Buzwagi and North Mara gold mines. According to Barrick Gold, which owns $63.9 \%$ of Acacia, on October 19, 2017, the dispute was resolved through a proposed framework where Acacia will make a payment of $\$ 300$ million to the government and economic benefits from Bulyanhulu, Buzwagi, and North Mara would be distributed on a 50/50 basis between a new operating company and the government. According to the company, the "government's share of economic benefits would be delivered in the form of royalties, taxes, and a 16 percent free carry interest in the Tanzanian operations [38].

\subsubsection{Technology}

Poor technology, lack of skilled personnel and absence of capital have been considered to be the major obstacles faced by the Tanzania government towards full exploitation of minerals resources. It is against this background that Tanzania government decided to reform its policies towards mining hence attract FDIs with expectation that the country would benefit. It is obvious that the principal beneficiaries of the mineral wealth have largely remained the transnational companies [7, 3]. The reforms have not to a larger extent made it possible for the technology to be transferred into the hands of the local communities or the state rather.

\subsubsection{Poverty and the Mining}

It was from the word go from the reforms that mining could contribute to poverty reduction in a number of ways, mostly through generating income and through creation of opportunities for growth for lateral or downstream businesses. This has been partially realized due to weak governance, hence failing to control multinational corporations which invested in mining. It is reported that there has been an increase in the levels of poverty contrary to people's expectations and the objectives of the Mineral Policy of 1997 $[11,27]$.

\subsubsection{Environmental Effects and Health Hazards of the Mining Activities}

The Mineral Policy of 1997, among other objectives, was meant to minimize or eliminate adverse social and environmental impact of mining activities to the surrounding local communities [1]. It was also reported that that thousands of villagers in Geita around mining operations are exposed to serious health hazards emanating from the mining activities [37].

\subsubsection{Promotion of Transparency in the Extractive Industry Sector}

Notably there has been a major public concern over the management of the mining sector and the benefits it offers to Tanzania and its people which led the government to launch various Commissions, namely the Kipokola Commission (2004), the Mboma Commission (2004), the Bukuku Commission (2005), the Masha Commission (2006), and the
Bomani Commission (2008). These Commissions found that Tanzania was receiving minimum contributions from the mining sector and that the mining operations lacked transparency and were shrouded in secrecy. The Bomani Commission recommended that Tanzania join the EITI. Tanzania joined the initiative in February 2009, and since then, it has been implementing the EITI's transparency standards [38].

The Extractive Industries Transparency Initiative (EITI) is a global standard for improving transparency and accountability in the oil, gas and mining sectors. It is an initiative that encourages citizens of resource rich to monitor how benefits from the extractive industry sector are generated, distributed and utilized (TEITI, 2018). Tanzania began implementation of the Extractive Industries Transparency Initiative (EITI) with a view to improving the good governance of its oil, gas and mining sectors. The EITI requires implementing countries to prepare and publish an annual report disclosing company payments and government revenues from the extractive sector. Since joining the EITI, Tanzania has produced seven EITI reports, which indicate that from July 1, 2008 to June 30, 2015, the government collected U\$ 2.76 billion from the extractive companies.

In October 2016, the government published the Mining and (Minimum Shareholding and Public Offering) Regulations 2016, which require Special Mining License holders to issue a minimum of $30 \%$ shares to the public and list on the Dar es Salaam Stock Exchange (DSE) within one year of receiving a new license and within two years for existing licenses.

\subsection{Lessons Learnt}

Lessons are numerous that can be learnt from the mining sector reforms in Tanzania, including but not limited to, the need for Institutional capacity and resources governance enhancement, weaknesses in the policy formulation process, and failure to oversee Corporate Social Responsibilities (CSRs), just to mention few lessons. The lessons are hereunder discussed.

\subsubsection{The Need for Institutional Capacity Enhancement}

Based on what has been discussed, there seems to exist a gap in relation to Tanzania's both institutional and legal frameworks to manage the sector. The lesson here is that either the capacity of institutions responsible for the daily execution of such procedures are very low or there is a lack of seriousness and patriotism from the side of those charged with the responsibility of overseeing the sector. Therefore, there is a need for a strong institutional mechanism for accountability to sanction government's performance, donor behaviour and investors' commitment and transparency with regard to their undertakings.

\subsubsection{Policy Formulation Process and the Local Communities' Involvement}

Communities have been the least regarded and historically 
neglected in policy and other discussions related to mineral sector development. As a result, negotiations and discussions have been primarily between governments and mining companies and have not involved those whose lives and livelihoods are impacted directly and usually adversely by mining operations. It is high time now the government put the modalities for local communities' involvement in the policy formulation process. The Mineral Policy of 1997, despite insisting on the communities' involvement, but the modalities are now not very clear. Involvement of the communities will not only give them an opportunity to air their concerns but would also avoid future conflicts.

It is important that the reform process is locally driven. It increases the public's sense of ownership and ensures commitment to implementation and sustainability. Public acknowledgement of policy failure by political leadership sends a powerful message to the public. It is a necessary and important step towards initiating change in policy regime. In addition, a participatory approach helps bring a wide range of stakeholders on board-the open dialogue, and the various "home-grown" programmes through which the reform process evolved, creates broad ownership and allows the government to formulate a reform programme that will not only be acceptable at home, but also acceptable to development partners and the 'would- be- investors'.

\subsubsection{Corporate Social Responsibilities (CSRs)}

With regard to Corporate Social Responsibilities (CSRs) the lesson learnt is that most of the LSMCs have only done the minimum. Most of the CSRs in existence now are only helping but not developing. The argument is that the LSMCs need to have CSRs that will affect the well-being of the local communities hence guaranteeing social licensing for mining companies, which will in turn put off the conflicts, which are now on increase.

\section{Conclusion}

The article has tried to offer a review of Tanzania's mining sector whereby it has been shown that many efforts have been undertaken by the government so as to increase the sector's contribution to GDP. Based on the review, it can be concluded that, reforms undertaken in the country's mining sector have led to some positive gains. For example, some of the success stories that are reported in the Tanzania's mining sector are increase in Foreign Direct Investment (FDI), rise of exports from mining and a varying mining sector contribution to government revenues. The sector's growth has also led to creation of job opportunities both within the sector and outside it in terms of services offered by their companies. However, it is also concluded that the reforms undertaken have not led to achievement of all expectations and in some situations conflicts have been the outcome. Some of the conflicts and the actual investment have led to displacement of local communities and destruction of livelihoods around the resource rich areas. This is to say that the current policy and legal environment in the mining sector following the economic reforms have not been able to fully create environment in which maximum benefits can be realized towards socio-economic development in the country.

\section{References}

[1] Chachage, C. S. L. (1995). Mining and environmental issues under SAPS in Tanzania: Examples from three case studies. In: Proceedings of the Policy reforms and the Environment in Tanzania. (Bagachwa, M. S. D and Limbu, F-Eds) 23-27 October 1995, Dar es Salaam. 251-266pp.

[2] Curtis, M., and Lissu, T. (2008). 'A Golden Opportunity: How Tanzania is failing to Benefit from Gold Mining'. Published by the Christian Council of Tanzania and National Council of Muslims in Tanzania, Dar es Salaam, Tanzania. http://www.businesshumanrights.org/Search/SearchResults?Se archableText $=$ Lissu + Curtis $\& \mathrm{x}=0 \& \mathrm{y}=0$._Accessed on May, 8th 2015.

[3] Darimani, A. (2005). Impacts of activities of Canadian Mining Companies in Africa. Third World Network- Africa, Accra, Ghana. 43pp.

[4] Economist Intelligence Unit. (2000). Country Profile Tanzania Country.eiu.com/tanzania. Site visited on $4^{\text {th }}$ October 2015.

[5] Epaphra, M. \& Massawe, J. (2016). Investment and economic growth: An empirical analysis for Tanzania. Turkish Economic Review, 3 (4), xxx-xxx.

[6] Fernandez, W. A. (2014). The Role of Mining in Economic Development in Namibia Post-2008 Global Economic Crisis. A research report submitted to the faculty of Engineering and the Built Environment, University of the Witwatersrand, Johannesburg, in fulfilment of the requirements for the degree of Master of Science in Engineering.

[7] Fisher, E. (2007). Occupying the margins: Labour integration and social exclusion in artisanal mining in Africa. Development and Change 38 (4): 735-760.

[8] Fraser, A and Lungu, J. (2006). For Whom the Windfall? Winners and Losers in the Privatization of Zambia's Copper Mines. Civil Society Trade Network of Zambia and Catholic Centre for Justice, Lusaka, Zambia. 42pp.

[9] Geita Gold Mine. (2004). Community relations and social responsibility.

[10] Gibbon, P. (1993). Social Change and Economic Reform in Africa. Scandinavian Institute of African Studies. Uppsala, Sweden.

[11] Kitula, A. G. N. (2006). The environmental and socioeconomic impacts of mining on local livelihoods in Tanzania: A case of Geita District. Journal of Cleaner Production 14: 34.

[12] Labonne, B. and Gilman, J. (1999). Towards Building Sustainable Livelihoods in the Artisanal Mining Communities: Social and Labour issues in Small scale mines. International Labour Organization, Geneva. 10pp.

[13] Lange, R. (2008) Land Tenure and Mining in Tanzania, Michelsen Institute, Bergen Norway. 
[14] Lange, S. (2006). Benefit streams from mining in Tanzania. A case of Geita and Mererani. Journal of Cleaner Production 14 (22): 397-404.

[15] LEAT (Lawyers Environmental Action Team). (2003) "Robbing the Poor to Give the Rich: Human Rights Abuses and Impoverishment at the MIGA Backed Bulyanhulu Gold Mine, Tanzania", Submission to the Extractive Industries Review of the World Bank, Maputo Mozambique, January 1317, 2003.

[16] Lugalla, J. L. P. (1995). The Impact of Structural Adjustment Policies on Women's and Children's Health in Tanzania. Review of African Political Economy No. 63.

[17] McMahon, G (2010). The World Bank's Evolutionary Approach to Mining Sector Reform. World Bank| Oil, Gas, and Mining Unit Working Paper. Extractive Industries for Development Series \#19. 48pp.

[18] Magai, P. S and Márquez-Velázquez, A. (2011). Tanzania’s Mining Sector and Its Implications for the Country's Development Working Paper No. 04/2011. 27pp.

[19] Maliyamkono, T. L. and Mason, H. (2006). The Promise. Tema Publishing and Siyaya Publishing (Pty). Dar Es Salaam, Tanzania. 619pp.

[20] Mogalakwe, M. (2006). The use of documentary research methods in social research. African Sociological Review, 10 (1) $221-230$.

[21] Muganda, A. (2004). Tanzania's Economic Reforms and Lessons Learned. Paper Presented at the Scaling Up Poverty Reduction: A Global Learning Process and Conference. Shanghai, May 25 - 27, 2004.

[22] Muhanga, M and Nombo, C. (2010). Local Government Authority policy responses to the Informal Sector in Morogoro Tanzania: seeing problems in an opportunity or seeing an opportunity in problems. African Affairs 28/2010.8 ISSN 1229-9308.

[23] Muhanga, M. I (2012). The Mining Sector Reforms in the Context of Fifty years of independence in Tanzania: (A book Chapter) in a book titled "A Review of 50 Years of Tanzania (Mainland) Independence": An Analysis of Some Key Development Issues (Urassa, J, K-Ed). Lambert Academic Publishing, German. ISBN-13: 978-3-659-21059-4 ISBN-10: 3659210595 EAN: 9783659210594. 100-120pp.

[24] Muhanga, M. I and Urassa, J. K. (2013). Mining Sector Reforms in the Context of Fifty Years of Independence in Tanzania: A Reflection of Mwalimu Nyerere's Legacy. A paper presented at Nyerere Memorial Lecture at Mzumbe University, Morogoro, Tanzania, October 2013.

[25] Muhanga, M. I. (2016). Tanzania's Mining Sector Reforms: Towards or Away from Mwalimu Nyerere's Ujamaa Ideology. Research on Humanities and Social Sciences, www.iiste.org, ISSN (Paper) 2224-5766 ISSN (Online) 2225-0484 (Online). Vol. 6, No. 21, 2016.

[26] Muhanga, M. I and Urassa, J. K. (2018). Mining Sector Reforms in the Context of Fifty Years of Independence in Tanzania: A reflection of Mwalimu Nyerere's legacy. Journal of Co-operative and Business Studies (JCBS), Vol (3) 2.

[27] Mwalyosi, B. B. R. (2004). Impact Assessment and the mining industry: Perspectives from Tanzania IAIA'04, Vancouver, Canada. [http://www.iaia.org/NonMembers/Conference] site visited on $09 / 05 / 2011$.

[28] Ngonyani, E. A. (2000). "Environmental Management and Protection Considerations in the Mining Industry: Examples of Contemporary Approaches to Regulations". Paper presented at the Government of Australia and United Nations Environment Programme Workshop on Environmental Regulation for Accident Prevention in Mining-Tailings and Chemicals Management 26 - 27 October 2000, Perth, Australia.

[29] Nyerere, J. K. (1974) Freedom and Development. Oxford University Press, Eastern African, Dar es Salaam.

[30] Oxford Business Group (2016). Tanzania encourages investment to broaden mining sector base. Available at: https://oxfordbusinessgroup.com/news/tanzania-encouragesinvestment-broaden-mining-sector-base. Site visited on $16^{\text {th }}$ August 2018.

[31] Peake, A. (2000). "A perspective on the small scale mining sector in South Africa". Mining World, August, 2000, p. 7.

[32] Portelli, B. (2005). The role of foreign direct investment in the context of economic reform. evidence from Tanzania. Centre for Technology, Innovation and Culture University of Oslo.

[33] Reed, D. (1996). Structural Adjustment, the Environment and Sustainable Development (London: Earthscan, 1996): 107 127.

[34] Roe, A. and Essex, M (2009). Mining in Tanzania - What future can we expect? The Challenge of Mineral wealth: Using resource endowments to foster sustainable development. Oxford Policy Management. London. www.opml.co.uk/document.rm?id=1360. Accessed on May, $3^{\text {rd }} 2015$.

[35] Rugumamu, S. M. (2005). Globalization Demystified: Africa's Possible Development Futures. Dar Es Salaam University Press, Dar Es Salaam. 238pp.

[36] Saunders, S. (2008) “Thousands Raid Barrick's North Mara Mine" http://www.protestbarrick.net/article.hph?id=358, Retrieved on 20th February 2010 at 17: 39 Hours.

[37] Tambwe, A. (2008). Tanzania losing out on minerals. The African Newspaper Issue No. 3225. p. 1-2.

[38] Tanzania Extractive Industries Transparency Initiative. (2018). Final Report For The Period July 12015 to June 30, 2016. March 2018. 246pp.

[39] Tanzania Investment Report, (2013). Reports on the Study of Foreign Private Investment. Dar es Salaam.

[40] UNCTAD (2005). Prospects for Foreign Direct Investment and the Strategies of Transnational Corporations, 2004-2007. United Nations Conference on Trade and Development, Geneva. 23 pp.

[41] UNCTAD, (2008). Trade and Development Report. United Nations publications, New York and Geneva. http://www.unctad.org/en/docs/tdr2008notes_en.pdf. Accessed on May, 19th 2015.

[42] URT (1997). The Mineral Policy of Tanzania. Ministry of Energy and Minerals. Dar Es Salaam, Tanzania. 32pp.

[43] URT (1998). The 1998 Minerals Act. Dar Es Salaam, Tanzania. 
[44] URT (2011). Investments Benefits Study Final Report, (Sustainable Management of Minerals Resources Projec.) Oxford Policy Management in association with Economic and Social Research Foundation (ESRF) and MTL Consulting Company Ltd. 160pp.

[45] UNCTAD, (2015a). World investment Report 2015 reforming international investment governance. United Nations Conference on Trade and Development. Geneva, Switzerland.

[46] UNCTAD, (2015b). Economic development in Africa: rethinking the role of foreign direct investment. United Nations Conference on Trade and Development. Geneva, Switzerland.

[47] Wanzala, P. N. (2007) Whose Development Counts? Political and Ecological Displacement of Bulyanhulu Mining Community in Tanzania, MA. Thesis, Norwegian University of Science and Technology, Norway.

[48] Zamora, A. (1999). "Small Scale Mining: A Social and Environmental Problem Turned into an Opportunity for Economic [http://www.dundee.ac.uk/cepmlp/journal/html/article66.html].

[49] Muhanga, M. I. and Malungo, J. R. S. (2017). The what, why and how of health literacy: a systematic review of literature. International Journal of Health, 5 (2) (2017) 107-114. doi: 10.14419/ijh.v5i2.7745.

[50] Mutahaba, G; Baguma, R and Halfani, M. (1993) Revitalizing African Public Administration for Recovery and Development; Kumarian Press.

[51] World Bank and ICMM, Community Development Toolkit,
ESMAP Formal Report Series, Report No. 310/05, World Bank, Washington, D. C., 2005.

[52] World Bank, Characteristics of Successful Mining Legal and Investment Regimes in Latin America and the Caribbean Region, Mining Staff Working Paper, World Bank, Washington, D. C., 1996.

[53] World Bank, Large Mines and Local Communities: Forging Partnerships, Building Sustainability. Mining, and Development Series, World Bank, Washington, D. C., 2002.

[54] World Bank, Latin America and the Caribbean: A Mining Strategy, World Bank Technical Paper No. 345, World Bank, Washington, D. C., 1996.

[55] World Bank, Mining Reform and the World Bank: Providing a Policy Framework for Development, Mining and Development Series, World Bank, Washington, D. C., 2005.

[56] World Bank, Strategy for African Mining, World Bank technical paper number 181, World Bank, Washington, D. C., 1992.

[57] Masanja, C. R. (2018). The Extent To Which Foreign DirectInvestment (Fdi) Contribute To The Growth Of Host Economies: Evidence From Tanzania. Business Management Review 21 (1), pp. 1-22 ISSN 0856-2253 (eISSN 2546-213X).

[58] Dupasquier, C. \& Osakwe, P. N. (2005). Foreign direct investment in Africa: performance, challenges and responsibilities. Journal of Asian Economics, 17 (2), 241-260. doi. 10.1016/j.asieco. 2005.07.002.

[59] Chuhan-Pole, P, Andrew L. Dabalen, A. L and Land, B. C. 2017. Mining in Africa: Are Local Communities Better Off? Africa Development Forum series. Washington, DC: World Bank. doi: 10.1596/978-1-4648-0819-7. 